\title{
2. An Analytic of Governing Asylum
}

Migration as well as asylum governance is crucially about affecting people's (im)mobility directly or indirectly. But what does this mean? Mobility studies provide vital answers to this question. The emergence of the burgeoning field of mobility studies has involved a turn from "sedentarist metaphysics" (Malkki 1995, 227; 1992) to a mobile ontology (see Adey 2006; Amilhat-Szary 2015, 22). The latter implies that everything is mobile, yet some things and people are relatively immobile - because of the different speed of movement, transformation and re-composition of things (ibid.). Consequently, a mobile ontology urges us to analyse the "relational politics of (im)mobilities" (ibid., 90-91; see also Cresswell 2010), i.e., "exploring how different people are placed in different ways to mobility, and thus different ways to power" (Adey 2006, 276). Cresswell (2006), for instance, highlighted that law and legal practice are crucially implicated in producing mobilities:

Legal documents, legislation, and courts of law themselves are all entangled in the production of mobilities. Mobilities are produced both in the sense that meanings are ascribed to mobility through the construction of categories, such as citizen and fugitive, and in the sense that the actual ability to move is legislated and backed up by the threat of force. (Cresswell 2006, 150-51)

The production of mobilities needs thus to be considered as crucially mediated by law and other elements of material-discursive arrangements of government (Thieme 2017, 245). Such arrangements have been the focus of the emerging field of "migration infrastructures" (Kern and Müller-Böker 2015; Lin et al. 2017; Thieme 2017; see also Star, 1999) which "has explored how mobilities are shaped, regulated, and controlled through a host of various policies, technologies, and practices" (Adey 2006, 276). Such infrastruc- 
tures constitute "socio-technical platforms" (Lin et al. 2017, 167) - "physical and organisational architectures, responsible for structuring, mobilising and giving meaning to movement through their particular arrangements" (ibid.) - that are themselves in constant transformation and thus only relative "moorings" (Adey 2006).

A crucial point is that such infrastructures do not merely facilitate and enable mobilities and moorings, but also produce them (Lin et al. 2017, 168). Considering the administrative arrangements of governing asylum as a form of migration infrastructure means to acknowledge that they are in movement too - and in constant need of stabilisation and adaptation. Furthermore, it means to attend to the material-semiotic practices that enact such governmental arrangements and thus produce specific (im)mobilities. I develop a conceptual framework that captures socio-technical practices of governing, governmental relations of power/knowledge and the networked arrangements (or infrastructures) of enacting mobilities. I do so by attending to the material-semiotics of government (2.1) and the governmentality of governing asylum (2.2), and I develop a notion of the Foucauldian dispositif to grasp the networked arrangements of government (2.3). To consider its involvement in governing mobile lives, I link these conceptualisations of government to a notion of territory and re-cording lives, which helps me to consider the socio-spatial effects of governing asylum (2.4).

\subsection{Material-Semiotics of Governing}

In this study, I approach asylum through the prosaic, heterogeneous and routine practices through which it is governed (see also Painter 2006). This explains why I use the term "governing" asylum: it highlights the multiple, open-ended, contested administrative practices devoted to resolve asylum claims. It also presupposes neither actors involved in these practices of governing (such as 'bureaucrats') nor a specific locus for them (such as 'the bureaucracy').

My research is informed by a practice perspective (Bourdieu 1977; Reckwitz 2003; Schatzki, Knorr Cetina, and von Savigny 2001). Such a perspective suggests that the individual and society, agency and structure are fundamentally interrelated: individuals cannot be meaningfully conceived of without the societal relations in which they are entangled and produced; in turn, 
structure is an effect of concerted acts of production and enactment. Agency is never independent of the structural relations in which it unfolds and to which it contributes. I draw upon a material-semiotic perspective which sees agency not exclusively as a matter of humans and their embodied knowledge (in what Bourdieu 1977, called a "habitus"), but as crucially enabled through "equipment" (Thévenot 2002), "devices" (Callon 2002) or "plugins" (Latour 2005). Such devices compose a material-discursive arrangement whose enactment produces asylum, its spaces and subjects. Combining insights of embodied and "tacit knowledge" (Polanyi 2009) with insights from material-semiotics thus allows to grasp "knowledge practices" for "managing complexities" (see Mol and Law 2002) such as those at stake in the governing of asylum.

\subsubsection{Case-Making}

I suggest a focus on "case-making" (Scheffer 2001; 2010) as the core administrative practice directed at asylum applications. The focus on case-making helps to grasp the complex conditions and considerations in the assembling of records along their trajectories (see Scheffer 2010). It offers valuable insights into the meticulous production of asylum, which necessitates an interplay of policies, officials, divisions, templates, discourses, buildings, and other material-discursive elements. Moreover, it allows a grasp of much of the micro-politics involved, since "case-making is situated and interested... it contributes to the loosing [sic] or winning, to punishment or release, to urgencies and right moments" (Scheffer 2010, $\mathrm{xv}-\mathrm{xvi}$, own emphasis). The work of case-making is thus strategic, as it aims to resolve asylum claims. Case-making shifts the attention of the analyst from empirically elusive 'decisions' taken by officials to the concerted and laborious material-discursive practices of assembling case files [Dossiers in German]. Case files consist of all the documents submitted by asylum claimants and the records produced along the administrative procedure, which render claims resolvable in an administrative order [Verfügung]: the asylum decision*."

1 Notions that have a very specific meaning in the asylum office and are marked with an asterisk (") should not to be confused with the everyday use of the terms. The decision" refers to the material-discursive letter and record that is (an attempt for) the closure of a case (see also Darling, 2014, for an account from the receiving end of such a letter). 
Case files are composed of procedure-related files each with their characteristic records. Asylum becomes assembled in records that mediate between partly internalised schemes of classification (Chapter 4) and other elements of the dispositif, namely human's entanglement with governmental arrangements and devices (Chapter 5). Records or files not only represent persons claiming asylum in bureaucratic practice, but are generative: they do not only represent but also construct their objects (Hull 2012a, 259). As Vismann $(2011 a, 8)$ pointed out, records "take effect in the formation of the three large entities on which law relies: the truth, the state, and the subject". Moreover, files "produce particular types of subjects" (Kelly 2006, 92) through the separation of what is documented - recorded - and what is left out of the person's life they represent (Hull 2012a, 260). Recording is a key practice of case-making because it establishes the material and symbolic traces of the case that an asylum decision* (and an appeal ruling) can potentially refer to. In this way, it provides the substance for a specific case: only what is "on the record" [aktenkundig] exists for citational practices (Butler 2011) in the proceeding (see subchapter 6.2). This is reflected in the common expression among officials "the examination of records has shown" in asylum rulings and in the sometimes regrettably voiced "absence of evidence in the records" which could substantiate another decision*. And practices of recording lives in case files involves a subtle disciplinary regime as Muckel (2000) rightly pointed out: ${ }^{2}$ records produce a crucial asymmetry of knowing that shapes encounters between people involved in recording and those being recorded (see also Callon 2002, 214); and records submit applicants to the peculiar rendering of their lives by caseworkers (see also Hull 2012a, 259).

I consider cases to become assembled in "processual events" (Scheffer 2007a, 183). The notion of processual events has been suggested by Scheffer (2007) to grasp the interrelatedness of the (macro-sociological) process and the (micro-sociological) event in legal procedures. He ponders:

The process may empower the event. The process may multiply its effects and consequences. In return, it can never fully determine the event's course. It remains contingent to some degree. The process allocates a certain competence to decide, to direct its course, to re-assess its past, or to declare its

2 Relatedly, Muckel (2000) attributed to records panoptic qualities - a reading I do not further pursue here. 
termination. This contingency is precisely the "junction" that is inherent in legal procedures. (Scheffer 2007a, 184)

In my case, I suggest that the pragmatics of governing asylum revolve around a number of key processual events: case openings, encounters, assignments, authentications, and closures (Part II). While such processual events are crucially scripted by legal, administrative, and organisational arrangements of agentic formations (introduced in Part I), the trajectories of various material-discursive components of the dispositif intersect in them, such as the biographies and bodies of claimants and officials, narratives of persecution and memories of current and previous cases, experiences and imaginations of places and lives in proximate and distant places, material case files, policy documents, computers and databases populating the offices and buildings of the asylum administration. Hence, a heterogeneous set of components with their histories and sets of dispositions meet in processual events of assembling case files, thus forging uncertain associations (see Latour 2005; Massey 2005) and rendering such events' outcomes contingent.

\subsubsection{Agency}

In a material-semiotic view, social entities such as states or societies are conceived as an effect of historically contingent processes of association and dissociation (Mattissek and Wiertz 2014, 160) or forms of ordering (Law 1994). Such a view refrains from attributing a stable identity or essence neither to human actors nor to macro-actors (Latour 2005) such as the "state", "bureaucracy", or "organisation", or what Foucault (1980) termed "universals" (adding to the former, for example, "law" or "sovereignty"). In this view, only heterogeneous elements interact and produce reality effects, the social entities just mentioned being amongst such effects (see Mitchell 1991; 2002; 2006). To start with, analytically, there is only socio-material practice. All the microand macro-actors remain to be assembled by the analyst (Callon and Latour 1981). Accordingly, rather than taking agency and power to be self-evidently located somewhere, I follow Mitchell (2002) in considering them in need of exploration and explanation:

It means making this issue of power and agency a question, instead of an answer known in advance. It means acknowledging something of the unre- 
solvable tension, the inseparable mixture, the impossible multiplicity, out of which intention and expertise must emerge. It requires acknowledging that human agency, like capital, is a technical body, is something made. (Mitchell 2002, 53)

Scholars of science, technology and society (STS) and actor-network theory (ANT) convincingly demonstrated that (scientific) knowledge is not the product of human agency and intentions alone (Pottage 2012, 167). They have asked to acknowledge the hybridity of agency and to treat agency as something to be achieved rather than a given. Their relational approach starts from a proposition of symmetry ${ }^{3}$ :

In actor network webs the distinction between human and nonhuman is of little initial analytical importance: people are relational effects that include both the human and the nonhuman ... while object webs conversely include people (...). Particular networks may end up being labelled "human" or "nonhuman" but this is a secondary matter. (Law 2009, 147, emphasis in original)

For my analysis, this means to begin only with heterogeneous participants in practices of governing asylum - more or less associated and active - and events of their formation or transformation (Latour 2005, 107, 113). Such participants in the governmental arrangement have to be distinguished regarding their capacity for "translation" (Callon 1986): between passive intermediaries which "transport (...) meaning or force without transformation" (Latour 2005,39 ) and mediators which actively "transform, translate, distort, and modify the meaning or the elements they are supposed to carry" (ibid.). Entities may behave in both ways in particular events "no matter what their figuration is" (Latour 2005, 57) in terms of size, form or concreteness. This is a crucial reason why agency cannot be determined outside practices: only what is able to mediate the outcome of practices can be considered agentic. My approach to the governing of asylum thus focuses on the whole range of

3 See also McMaster and Wastell (2005) for a discussion of this widespread misunderstanding of actor network theory (ANT). What ANT suggests is to dissolve the simple ontological dichotomy between subject and object, between the human and technology; to acknowledge and take into account the involvement of variously composed actors in the course of events; and to map the controversies over their agency (see Latour 2005, 52-55). 
material-discursive devices involved in the production of agency (Chapter 5). To emphasise the provisional and tentative character of agency, I speak of "agentic formations" - composite actors, part human, part equipment (see Rabinow 2003) - that constitute caseworkers, the asylum office and its subdivisions and assemble asylum cases towards their resolution.

\subsection{Governmentality}

My conceptual approach situates the everyday practices of asylum case-making in a governmental regime of practices, which I understand through a Foucauldian notion of governmentality. I thus share with Foucault the concern with the how of government (see Dean 1999) - the regime of practices it encompasses. Foucault focused on schemas and technologies that epitomise governmental rationalities, such as the Benthamian Panopticon for the disciplinary technologies of imprisonment famously analysed in his Discipline and Punish (Foucault 2008). He showed that forms of programming were extremely effective in inducing changes in how government was imaginable and allowed for distinctions between true and false. However, Foucault was explicitly not interested in what he called the "witches' brew" (Foucault 1991, 81) of everyday prison life and how programmes of government shape and are (re-)shaped in it. ${ }^{4}$ Despite the fact that, as Foucault (1991) pointed out, programmes of government crucially affect everyday practices of governing, his approach did not illuminate them.

I take a different approach to the governing of asylum by, on the one hand, considering the "witches' brew" of everyday, mundane and routine practices of assembling asylum cases towards their resolution. On the other hand, I consider the regime of practices as the rationalities and technologies of government in which the former become stabilised and transformed. I suggest reading Foucault through a material-semiotic lens and asking how rationalities of government are concretely translated and transported or

\footnotetext{
4 He stated that "it is absolutely true that criminals stubbornly resisted the new disciplinary mechanism in the prison; it is absolutely correct that the actual functioning of the prisons, in the inherited buildings where they were established and with the governors and guards who administered them, was a witches' brew compared to the beautiful Benthamite machine" (Foucault 1991, 81).
} 
transformed (Dölemeyer and Rodatz 2010, 198). Instead of focusing - in a genealogical manner - on the analysis of text, language, and discourse and how they exercise power, such a perspective rather traces the material-discursive relations and the regime of practices in which such relations come to manifest and thus perform programs of government (ibid.). I am convinced that in order to make sense of the prosaic practices of government, one has to attend to the finalities, rationalities, and technologies of power that enable and sustain them.

Accordingly, this book incorporates elements of an "analytics of government" (Dean 1999, 22-23) that considers the ways in which practices of governing asylum draw upon and perform particular rationalities and technologies of power (see also Gottweis 2003). To include these rationalities in the analysis of everyday practices of governing allows me to account for the "intellectual machinery" (N. Rose and Miller 1992, 280) of government. This refers to the theories and conceptualisations or "rationalities", or in Foucault's terms the "grids for the perception and evaluation of things" (Foucault 1991, 81), that make the world apprehensible and tangible for programmes of government with their aims or "finalities" (Foucault 2006, 137). Apart from these finalities and rationalities of government, technologies are key: instead of focusing on abstract principles of rule, the notion of technologies draws attention the specific procedures, mechanisms, and tactics involved and materialising in governmental practices.

\subsubsection{Finalities, Rationalities and Technologies of Government}

Government, in Foucault's terms $(1997,68)$, is "an activity that undertakes to conduct individuals throughout their lives by placing them under the authority of a guide responsible for what they do and for what happens to them" (in N. Rose, O'Malley, and Valverde 2006, 83). ${ }^{5}$ According to Foucault, government historically evolved as an "art" in the sense of a method, a technology to structure the field of potential action of people (Foucault 1984, 338; 2004b, 182), often briefly referred to as the "conduct of conduct" (Dean 1999, 10). This art aims at organising thought and action based on principles of rationality and governmental technologies, or "governmentality" (ibid.).

5 A Foucauldian notion of government is thus not only able to capture the management of political structures but also that of institutions, families, or the self (Flynn 1985, 533). 
Government in this sense stands opposed to sovereignty, as it does not have a single finality (such as obedience to the laws) but "a whole series of specific finalities" (Foucault 2006, 137). Such aims or finalities are, for instance, the furthering of wealth of a population, its provision with the necessary means of subsistence, or the securing of its ability to reproduce (ibid.). Government then is a matter of "disposing things: that is to say, of employing tactics rather than laws, and even of using laws themselves as tactics to arrange things in such a way that, through a certain number of means, such and such ends may be achieved" (ibid.). However, as Li $(2007,9)$ highlighted, such "'finalities' may be incompatible, yielding interventions that are in tension with one another, or downright contradictory". Considering the governing of asylum, finalities of the rule of law and humanitarianism, the externalisation and deterrence of asylum claim-making, and efficient administration meet each other awkwardly in the asylum administration (see Chapter 8).

Foucault's notion of rationalities implies that particular sets of practices involve and are organised by rationalities as specific ways of thinking and styles of reasoning: "Rationalities are ... practical rather than theoretical or discursive entities. They are forged in the business of problem solving and attempting to make things work" (Garland 1997, 184). In question is, accordingly, never the rationality of a single action, ${ }^{6}$ but the rationality informing practices of governing asylum "to make things work" (ibid.): for instance, legal, bureaucratic, economic forms of reasoning that all come with a certain form of analytical language, particular objectives, and technologies of management, organisation, and control (see Garland 1997, 185). In contrast to a genealogically-oriented analysis, I am less concerned with the shift in the central rationalities of governing asylum. Rather, I suggest that rationalities are multiple, sometimes contradictory and resisted in practice. I thus try to map rationalities that intersect in the governing of asylum and draw atten-

\footnotetext{
6 For avoiding misunderstandings, I want to clarify here that the Foucauldian notion of "governmental rationalities" relates to "regimes of practices", not behaviour or action. The notion of rationality adopted in this study does not refer to the idea of rational behaviour, as actor-centric, rational choice perspectives imply (even with potentially unintended consequences); neither does it refer to rational, intentional action by 'knowledgeable and capable' human actors as structuration theory suggests (Painter 2006, 762).
} 
tion to the technological "arsenal" (Gnosa, 2015) that has evolved to resolve asylum claims.

Foucault's notion of governmental technologies refers to the "complex of practical mechanisms, procedures, instruments, and calculations through which authorities seek to guide and shape the conduct and decisions of others in order to achieve specific objectives" (Lemke 2007, 50). Technologies of government are often associated with a particular rationality (Dreyfus and Rabinow 1983, 142). They include, but are not limited to,

methods of examination and evaluation; techniques of notation, numeration, and calculation; accounting procedures; routines for the timing and spacing of activities in specific locations; presentational forms such as tables and graphs; formulas for the organization of work; standardized tactics for the training and implantation of habits; pedagogic, therapeutic, and punitive techniques of reformulation and cure; architectural forms in which interventions take place (i.e., class- rooms and prisons); and professional vocabularies. (Lemke 2007, 50)

This notion of technologies thus not only refers to material devices, but also encompasses symbolic devices (ibid.). They can be distinguished into technologies to govern others - namely those "seeking to discipline the individual body or to regulate population processes" (Lemke 2007, 49) - and "technologies of the self" as well as "political technologies of individuals" (ibid.). Technologies of the self enable the self-guidance of subjects and their formation as ethical beings (ibid.). Political technologies of individuals have enabled our formation as political beings, as they have "led to recognize ourselves as a society, as a part of a social entity, as a part of a nation or of a state" (Foucault 1988b, 146). All of these technologies are to some extent involved in the governing of asylum.

Technologies of governing others pervade the processual events of case-making. They allow for the specification of the subject matter and legal competence, the setup of the hearings that allow caseworkers to speak in the name of the state and include things in - and exclude others from - the record, the regulated assignment and distribution of authorship, the access to and definition of authoritative knowledge and authentication techniques, and the writing devices that allow for a cases' closure in an asylum order (see Chapter 6). Technologies of the self and political technologies of individu- 
als are less obvious but nevertheless crucial in the government of those governing. They appear in reflexive and ethical principles of caseworkers and their superiors (Part III) and their compliance with calculative techniques to render case-making more efficient (subchapter 8.2) or in the adoption of a protective stance concerning the 'system' or the nation (see also Affolter 2017; Fuglerud 2004).

\subsubsection{Law as a Rationality and Technology of Government}

Asylum procedures thrust upon their analysts a need to account for the exclusionary politics of inclusion they implicate. Who or what can account for the sovereign act of drawing the boundary between those who are admitted and those who are not? Most commonly, it appears, the answer to this question is sought in the law and its implementation. A common difficulty of researching the legal, however, is that it offers such a forceful language of reason - as well as a mode of thinking and doing - that the social scientist can hardly escape (see Bourdieu 1994). It is hard to get hold of the legal sociologically, that is, outside the realm of legal rituals of self-referentiality (Latour 2010, 271). Associations considered legal mediate particular sets of relationships. Such relationships are, to various extents, stabilised by the citational practices of a legal authority associated with them (ibid.). This means that "legal judgments are both statements and deeds. They both interpret the law and act on the world" (Douzinas and Warrington 2012, 3). In other words, the legal adds a property to relationships that may - if enacted - become forceful. For this reason, engaging the legal meta-register has both empowering and subjugating effects (see section 2.4.2). Such effects are, arguably, particularly strong in the example of asylum applications. But how is it possible not to reify law while acknowledging its significance in the governing of lives? I suggest it takes a perspective that does not simply presume its existence, but traces the material-discursive associations through which it is produced empirically.

Law appears in various forms in the governing of asylum: the legal operates as a crucial rationality of governing asylum that is involved in shaping its object (see Chapter 8). Moreover, it has the appearance of a somewhat paradoxical technology: it is endlessly superficial in its grasp of existence and life (in all its qualities), yet still profound in its impact on existential relations 
of all sorts through its associative force (Latour 2010, 267). As Latour (2005) suggested:

It's not only that law, for instance, is unexplainable by the influence social forces exert over it; and it's not even true to say that law has to explain in turn what society is, since there is no society to be explained. Law has much better things to do: one of them is to circulate throughout the landscape to associate entities in a legal way. (Latour 2005, 239)

But "associating entities in a legal way" is by no means an innocent undertaking as Douzinas and Warrington $(2012,4)$ pointed out: "Legal interpretations and judgments cannot be understood independently of this inescapable imbrication with - often violent - action. In this sense legal interpretation is a practical activity, other-orientated and designed to lead to effective threats and - often violent - deeds. This violence is evident at each level of the judicial act." They question the widespread assumption in critical legal theory that "the rightness, fairness or justice of the interpretative enterprise will bestow its blessing on the active component of the judgment and justify its violence" (ibid.). They convincingly argue that justice does not arrive from appropriate interpretation, but can only arise from the judgement: justice cannot be found in law itself, but may arise in its momentary suspension in the sovereign act of inscription, of associating life with law. Relatedly, Aretxaga (2003) maintained:

The hold of the law, the impossibility of extricating oneself from it, rests on the force of its performance which, lacking symbolic content, can create an obsessive attempt at interpretation, at translation of mere force into the language of reason. What is ultimately untranslatable about the performance of the law, the dimension of pure performativity that constitutes the law's authority, is the arbitrariness of its power to decide life and death. (Aretxaga 2003, 407)

Arguably, a lot of law's potency as a meta-register for (re)shaping relationships arises in this reading from what could be considered a sovereign conjuncture - i.e., the moment of fundamental and precarious indeterminacy of existence. This sovereign conjuncture of being reduced to "bare life", in Agamben's (1998) terms, serves “to affirm a juridical order in which lawful- 
ness, right, is suspended in the name of law" (Aretxaga 2003, 405). The potentiality of such sovereign conjunctures always resides in law and renders law such an effective political technology (Barry 2001). But beyond this, I suggest the character of law as a prosaic meta-register makes it conducive for practices of reassembling the social, thus not only to "act on the world" (Douzinas and Warrington 2012, 3) but also to re-enact the world. Where the meta-register of law becomes enacted, it turns dreadfully real, indissolubly tied to webs of existence (see section 2.4.2).

Traces of this notion of law can also be found in representations of governing asylum where asylum orders are considered a sovereign act directed at an individual. However, sovereign acts of law are never just about an individual but always about collectives: those who never had to ask for admission (citizens, 'cosmopolitans'), those already admitted, those awaiting admission, and those potentially come to be admitted. Accordingly, boundaries of asylum are never simple lines, but rather complex composites. How can we account for their relationality?

\subsection{The Dispositif}

To grasp the networked arrangements in which asylum becomes governed, I draw on Foucault's notion of the dispositif(Foucault 1980, 194). ${ }^{7}$ The dispositif refers to networked relations between heterogeneous elements of government - "the said as much as the unsaid" (ibid.). A dispositif connects "forms of practical knowledge, with modes of perception, practices of calculation, vocabularies, types of authority, forms of judgement, architectural forms, human capacities, non-human objects and devices, inscription technologies and so forth" (N. Rose 1999, 52) involved in practices of government. It

7 Two different yet related concepts could be used to grasp the arrangement or disposition of things in which practice takes place: the Foucauldian (1980) dispositif or apparatus, and the Deleuzian (1988) agencement, or assemblage (see also Callon 2007b; Deleuze and Guattari 1988). Agencements refer to "hybrid collectives" that are "comprised of human beings (bodies) as well as material, technical and textual devices" (Çalışkan and Callon 2010, 9). The two concepts are closely related and can be fruitfully thought together, yet without erasing the differences between the two (Legg 2011, 131). Rabinow (2003) suggested conceiving of "assemblages ... [as] secondary matrices from within which apparatuses [dispositifs] emerge and become stabilized or transformed" (ibid., 56). 
thus not only encompasses discursive formations but also technologies of government and non-discursive practices (Bührmann and Schneider 2008). As Walters $(2012,146)$ proposed, such a notion helps to move the analysis of governance beyond the programmatic, "to grapple with the ways in which things hold together in a rough and ready way that no one quite planned, in which all bits and pieces find a provisional coherence even though they don't quite fit together". The notion of the dispositif thus allows me to tease out the relationality, tentativeness and heterogeneity of what is involved in action, knowledge production, or government.

Introduced by Foucault as "a notion of emergent ordering" (Pottage 2011, 164), a dispositif has to be moreover thought of as strategic (Foucault 1980, 195), as a response an "urgent need" (ibid.) or as a sustained problematisation (Rabinow 2003, 55). In the case of asylum, it can be seen to have emerged as a response to the (growing) problematisation of people claiming rights of a state of which they are not citizens (on the basis of the Geneva Refugee Convention). Agamben $(2009,20)$ emphasised in his take of dispositifs that they are crucially about to the production of subjectifications: "Apparatus [dispositif] is first of all a machine that produces subjectifications, and only as such it is also a machine of governance." While I do not consider the asylum dispositif to be first of all about subjectifications, it still brings about a whole range of asylum subjects - asylum seekers, claimants, recognised refugees, temporarily admitted persons, rejected asylum seekers - through its particular configuration of power and knowledge. ${ }^{8}$

\subsubsection{Enactment and Multiplicity}

A crucial question concerns the relationship between practices of government and the realities they are involved in constructing. Science and technology studies (STS) and actor-network theory (ANT) have highlighted that "knowing, the words of knowing, and texts do not describe a pre-existing world. They are rather part of a practice of handling, intervening in, the

8 According to Foucault, power and knowledge need to be considered in a mutual condition of existence (Cnosa 2017, 17-18). The dispositif of asylum accordingly involves particular "technologies of power" (Dreyfus and Rabinow 1983, 188) through which officials can act upon applicants in the asylum procedure and a particular "will to knowledge" (Foucault 1978,65 ) about the subject deserving protection and its origin. Practices of government generate insights that are updating this will to knowledge in certain ways. 
world and thereby of enacting one of its versions - up to bringing it into being" (Mol and Law 2002, 19). ${ }^{9}$

The technologies and knowledge practices of governing asylum do not act upon a pre-existing world either, but are performative: this means that "they have effects; they make differences; they enact realities; and they can help to bring into being what they also discover" (Law and Urry 2004, 393). This is compatible with Butler's (2011, xii) notion of performativity "as the reiterative and citational practice by which discourse produces the effects that it names". Hence, knowledge practices such as those involved in the governing of asylum - for instance, practices of knowing origin and persecution stories of applicants through hearings, of knowing the 'situation' in countries of origin through field missions and country of origin information, but also of 'knowing' future numbers of asylum applications through risk analysis not merely have a descriptive relationship with the world(s) they denote but a generative one. What I suggest here is that performative practices are crucial for the dispositif's emergence and transformation as "a kind of arrangement that is, paradoxically, constituted by its own effects" (Pottage 2011, 164).

Furthermore, as the governing of asylum involves multiple knowledge practices, this means that multiple realities are enacted. What science and technology studies (STS) and actor-network theory (ANT) have suggested for research methods (Law and Urry 2004) and practices of 'technoscience' (Law 2004b), thus also applies to practices of government: "The argument is that there isn't one set of practices. Instead there are lots of them. And those practices, this is the really crucial shift, are all enacting and re-enacting putative realities" (Law 2004b, 5). By consequence, the dispositif of governing asylum cannot be expected to generate a single coordinated network of practices and a single coherent reality, but multiple networks and multiple realities. Mol (2002) has demonstrated this for the body: while in theory it may be single, each practice of medical diagnosis and treatment concerned with the body generates its own material-discursive reality of it. Taking the example of atherosclerosis, she has highlighted that each diagnostic approach to this illness creates its own version of the body - it thus becomes multiple

9 This has been suggested for scientific laboratories (Latour and Woolgar 1979; Law 1994); for immunology (Latour 1988); markets (Callon 1998); the economy (Mitchell 2002); but also for the state (Mitchell 2006; borders and sovereignty (Salter in Johnson et al. 2011, 66-67); and refugeehood (Mountz 2011a). 
(Law 2009, 151-52; Mol 2002). The same can be argued for asylum: each approach to asylum in terms of specific knowledge and inscription practices in the administration creates its own version of it - a legal status, a statistical record, a welfare burden, a victim subject - which means it becomes equally multiple. Coherence between these versions of asylum, if achieved at all, is only a rare and fleeting accomplishment. This implies that "most of the time and for most purposes practices produce chronic multiplicity. They may dove-tail together, but equally they may be held apart, contradict, or include one another in complex ways" (Law 2009, 152 emphasis in original). An account of how realities relate cannot escape complexity, since they are essentially irreducible to one another (Latour 1988).

As Butler $(2010,152)$ has highlighted, performative enactment of realities is prone to failure, or as she says, it may "misfire", as "it is only under certain kinds of conditions, and with no degree of predictability that theoretical models successfully bring into being the phenomenon they describe". According to Callon (2010), misfires or "overflows" are the rule rather than the exception, and they are constitutive of any politics in the enactment of realities.

Saying and doing the economy - because all economies are said and done (Çalışkan and Callon 2009) - means entering into the agonistic field where the delimitation-bifurcation between the economy and politics is constantly being debated and played out. Structurally, the performativity of economics implies a demarcation between that which is economic and that which is not. Every economic performation programme calls for a counter-programme which takes as its starting point that which was left out, to propose another definition of the economy. (Callon 2010, 165)

Replace the economy" with "law" (or equally "the state"), and this excerpt quite well fits my case in which the association between law and its outsides is a matter of deliberation and contestation (see Chapter 7). There is thus a politics that arises from the multiplicity of realities or ontologies and their constitutive outsides. The notion of an "ontological politics" works "to underline this active mode, this process of shaping, and the fact that its character is both open and contested" (Mol 1999, 74-75). We thus end up with "fractional realities" in Law's $(2004 a, 6)$ terms, whose relations are uncertain: fractional asylums and enacted subjects. There are thus multiple networks 
and multiple realities of asylum - at times fitting together well, at times contradicting each other - that are enacted through the asylum dispositif. The fragmented networks of practices and rationalities of government of the dispositif (tend to) produce fractional realities of asylum and thereby also spaces and subjects.

\subsubsection{Associations}

As suggested above, I do not consider power and agency as givens, but instead trace the material-discursive relations or "associations" (see Latour 1984) in which they circulate. The dispositif of governing asylum has emerged and has been continuously (re-)assembled through the multiplicity of humans, materials, discourses, and strategies that have become associated to act upon the "urgent need" (Foucault 1980, 195) of asylum claim-making. The dispositif thus consists of the associations of heterogeneous elements enrolled in the cause of resolving problematisations or governmental 'crises' related to asylum. Associations tie dispersed practices together and stabilise them in a dispositif and are thus essential for power and agency. Such a relational understanding of agency resonates well with Foucault's "microphysics of power" in which power is not something to be possessed but rather exercised through, for instance the disciplinary techniques of the penitentiary prison (Gordon 1991, 3). Paraphrasing Latour (1984), I suggest that a relational, material-semiotic notion of power implies that "power lies in associations". ${ }^{10}$ In this view, it is the heterogeneous associations with which caseworkers are entwined that allow them to exercise power over asylum applicants. It is only through these associations that caseworkers are capable of affecting applicants and their lives qua case-making and enacting a particular governmentality. ${ }^{11}$

Drawing on Law (2009, 148-49), three modes of association that stabilise governmental arrangements such as the asylum dispositif can be distin-

10 Latour $(1984,277)$ highlighted that "the only way to understand how power is locally exerted is ... to take into account everything that has been put to one side - that is, essentially, techniques". He suggested that this notion was "in effect the same result as that obtained by Michel Foucault" (ibid., 279n18) in Discipline and Punish (Foucault 2008), merely extended to a wider range of (material) techniques. Accordingly, Latour's (1984) notion of power can be well combined with Foucault's (1980) later developed notion of the dispositif, which incorporates such material techniques, discursive and non-discursive practices.

11 One could thus aptly speak of the dispositif's governmateriality. 
guished: material, discursive, and strategic associations. The dispositif is stabilised in material associations to, for instance, buildings, documents, and analogue and digital devices enrolled in it. Such material associations are by tendency more stable than non-material or bodily elements of arrangements (ibid., 148). Yet, it is not primarily their form that makes material associations last, but the network they are entangled in. The second form, discursive associations, define the "conditions of possibility, making some ways of ordering webs of relations easier and others difficult or impossible" (Law 2009,149 ). Central to the governing of asylum are discourses of, for instance, human rights or refugee protection, the security of the population, or the rule of law (Bigo 2002; Gorman 2017; Zetter 2007). The dispositiffurthermore features strategic associations: "teleologically ordered patterns of relations indifferent to human intentions" (Law 2009, 148) that tie claimants to those governing. Strategic associations refer to the dispositions, manoeuvres, and techniques that allow some to govern others - Foucault's understanding of strategies (Gnosa 2015, 135). Crucial in the case of governing asylum are, for example, manoeuvres of defining what is 'relevant for the case' in asylum hearings or dispositions of considering some things submitted by applicants as decisive evidence (see Chapter 6).

I thus consider the different ways in which the dispositif of governing asylum becomes stabilised in material, discursive and strategic associations. The stabilising effect of such associations on governmental arrangements offers another analytical window to the obsession of administrative practices with documents and records, the pervasiveness of bureaucratic and legal discourse, but also forms of spatiotemporal ordering and bodily inscriptions (see Gnosa 2015, 128).

\subsection{Complex Composites of Space and Power}

Thinking asylum governance along the lines outlined above has also consequences for the conception of space: it takes a relational notion of space to grasp how people's lives-as-flows become entangled in relational politics of (im)mobilities. Thinking of space and power relationally in geography has involved a turn to topology and topological notions of space (see Allen 2009; 2011a; 2016; Allen and Cochrane 2010). These novel conceptualisations of space in topological terms have proven to be a promising endeavour. They 
have led to the introduction of a range of metaphors to rethink spaces as twisted, folded, bent or stretched. They have thus introduced a novel view of the networked forms of sociality and power. Allen (2009; 2011b; 2011a; 2016) has provided the most sophisticated elaboration of topologies of power so far. He suggests a topological view of power to grasp what he calls the "quieter registers of power" (Allen 2016, 2). These refer to "the ability to get others to do things that they would otherwise not have done [which] is reproduced, yet often changes as the relationship is folded or stretched through time to enable powerful actors to interact directly or indirectly with others elsewhere" (ibid.). ${ }^{12}$

My conceptions of space and are informed by such a topological perspective - I share, for instance, Allen's view that power's intensity is not a matter of Euclidean distance. Yet I suggest to draw upon a notion of governmentality and material-discursive associations to grasp "how it is that actors are able to make their presence felt in more or less powerful ways that cut across proximity and distance" (Allen 2016, 35). Allen's (2016) view of power, despite being avowedly informed by actor-network theory, appears to miss consideration of a crucial point: that there is no "hidden presence of some social forces" (Latour 2005, 5). This means power (or rather: government) does not have any reach in the vacuum: it needs a means of transportation, i.e., emissaries (Law 1986) or connectors (even if it is just computer bytes) that associate also physically dispersed locations and are thus traceable by the analyst (Latour 2005, 25, 176). I thus pursue a somewhat different approach to space and power. I follow Massey $(2005,9)$ in thinking of space relationally as a "simultaneity of stories-so-far" - of things and people that are related to it. This is also remarkably close to Foucault's (1986) notion of space outlined in his essay "Of Other Spaces":

12 This conception of these "quieter registers of power" has a startling resemblance with Foucault's notion of governmentality as acting on others actions, or "the conduct of conduct" (Dean, 1999, 10-11) which also occurs as "governing at a distance" (Rose et al, 2006, 89). However, it appears to me this connection is not developed. This is also reflected in his notion of the "power of reach" (Allen 2016; Allen and Cochrane 2010) that "can reveal how different actors work power by drawing things within reach or placing it beyond reach" (John Allen, Oral Communication, Workshop at the Department of Geography, University of Zurich, 15 May 2015). 
The space in which we live, which draws us out of ourselves, in which the erosion of our lives, our time and our history occurs, the space that claws and knaws at us, is also, in itself, a heterogeneous space. In other words, we do not live in a kind of void, inside of which we could place individuals and things. (...) we live inside a set of relations that delineates sites which are irreducible to one another and absolutely not superimposable on one another. (Foucault 1986, 23)

Space in this sense is not abstract and empty, but produced in, and at the same time limited by, practices that associate things and people with it - and exteriorise others. It is the material-discursive webs of relations that (dis) associate things and the living.

\subsubsection{Mobile Territories}

Foucault's notion that the government of people occurs via the government of things hints at the host of technologies mediating the social (Latour 2005; Lemke 2004; Raffestin 1980). Such technologies are crucial for disassociating 'refugees' from 'non-refugees'. In practices of knowing a 'refugee', both are produced as material-discursive realities: humans-as-refugees and humans-as-rejected-asylum-seekers. Such knowledge practices evoke and inscribe particular geographical and historical conjunctures, such as spaces of asylum, spaces of persecution and flight, and spaces of expulsion. These spaces are themselves mobile in the sense that the material-discursive arrangements that enact them are evolving and transforming. And they are crucially co-produced by those seeking asylum and claiming protection, and those involved in the 'management' of asylum (Mezzadra and Neilson 2012). Expanding on the insights from the literature on the mobility of borders (Mountz 2003; 2011b) and border struggles (Squire 2014; Tsianos and Karakayali 2010), I introduce a notion of "mobile territory", a spatiotemporally evolving meaningful correlate (see Delaney 2005) that is limited by and produced in practices that associate things and people with it (see also Painter 2010).

Such a notion of territory builds on the relational and material-semiotic notion of space introduced above. It adds to insights from mobility studies by considering not only the mobilities fabricated in enactments of governmental arrangements, but also the reassembled socialities (or literally "social 
geographies") this produces. ${ }^{13}$ It thus rejects nation-state territory as both a container space and a singular, given entity. Territories are, in this view, multiple, overlapping, and fragile effects of socio-technical practices of government (Painter 2010, 1115; see also Braverman et al. 2014; Brenner and Elden 2009). According to Painter (2010, 1115), "the territory-effect is generated by and depends on networked relations". In contrast to the common view in geography, territory and network are therefore not only commensurable forms of spatial organisation but are intimately related in practice (ibid.). I argue that as the lives of those seeking refuge are recorded in terms of asylum, not only their "identities are scripted" (Mountz 2010, 90), but also new exclusionary spaces as well as spaces of the possible - what I call mobile territories - are produced as an effect (see also Braverman et al. 2014; Painter 2010).

\subsubsection{Re-Cording Lives}

To analyse the mobile territories of governing asylum, I introduce the notion of "re-cording": it refers to the (dis)associations invoked in the governing of asylum that entangle applicants' past and future lives with networked arrangements of government and produce prosaic, fragile and contested territories as an effect. ${ }^{14}$ Re-cording is only a pretext for becoming captured in the time-space of a particular mobile territory. If to govern lives of people seeking asylum thus means to re-cord them territorially, they are importantly involved in this process: starting by the act of claim-making. While re-cording may capture their lives-as-flows to various extents in territories and with potentially profound consequences (including detention and

13 This resonates with Mitchell's $(1991,78)$ claim that it is crucial to "examine the detailed political processes through which the uncertain yet powerful distinction between state and society is produced. The distinction must be taken not as the boundary between two discrete entities, but as a line drawn internally within the network of institutional mechanisms through which a social and political order is maintained."

14 Painter's (2010) notion of territorial "coding" denotes a similar process - the categorical association of people's lives with certain material-semiotic spaces. The notion of "re-cording" more strongly emphasises the importance of stabilising such a coding in material-discursive records. It carries a double meaning of "recording" in the sense of grasping and protocolling applicants' lives; and the renewed "cording" indicating the material-bodily cords by which applicants become tied up in specific relations to territorial conjunctures. 
deportation), they also seek certain territorial relations (see also Murphy 2013) with territories of protection (and consequently residence). Governing asylum thus produces the subjectivities and a range of spaces of asylum some of them suffered for (see Moore 2005), others concomitantly unwanted and resisted.

Entering the asylum procedure through claim-making implies a particular subjectification as disposable subjects ${ }^{15}$ - quite in the sense of Agamben's (2002) homines sacri. The procedure through which asylum seekers' eligibility to protection is evaluated is at the same time the procedure through which their deportability is sought (see also Achermann 2008, 64). Yet, in the quasi-universal legal right to claim protection outside the country of origin also lies a considerable empowerment of people who were not lucky in the global "birthright lottery" (Shachar 2009). With their act of claim-making, they become legal subjects and therefore have for once the law on 'their side' as they have an opportunity to influence the "state of conviction" (Chapter 7) in their sense. It is in this sense that "games of truth" (Foucault 2014a) in asylum case-making are open, even if the "arsenal" (Gnosa 2015, 153-55) to impact the outcome is unevenly distributed.

While claimants are encountered by host states as noncitizens who strive for legal residency (see also Spiro 2008), their claims for refuge and their resistance to become governed (solely) in terms of asylum have to be considered as "acts of citizenship" (Isin 2008). Following Rancière's (2004) considerations on the Rights of Man, asylum is to be understood not only (or not even primarily) as a (legal) right of the non-citizen (of 'man') but as a "political predicate": "Political predicates are open predicates: they open up a dispute about what they exactly entail and whom they concern in which cases" (Rancière 2004, 303). This allows us to attend to the politics of relations that are shaped in the name of asylum: "The point is, precisely, where do you draw the line separating one life from the other? Politics is about that border. It is the activity that brings it back into question" (ibid.). Enacting the border (or, rather, the border correlate or territory) to separate one life from the other, the citizen from the asylum seeker, or the one protected from the one rejected, means to open "an interval for political subjectivization" (ibid.,

15 The deeper sense of the notion is well captured in German through two meanings of "disposable" subjects: verfügbare (available) but also entbehrbare (able to be thrown away) Subjekte. 
304). With their acts of border-crossing, claim-making, performing as refugees, and insisting on their right to asylum and residence, asylum seekers thus defy the "border's capture" (Soguk 2007) - or what I would call with Painter (2010) "territorial capture" - and become agents of an "insurrectional politics" (Soguk 2007).

\subsection{Summary}

In this chapter, I have outlined an analytic of governing asylum. This analytic allows us to understand how asylum is produced - as an object, subject, and a set of spatiotemporal relations - in situated practices of government that rely on a host of technological devices, forms of knowledge, and rationalities. It avoids common starting points such as law, the state, or bureaucracy and suggests an avenue for rethinking practices of granting or rejecting asylum claims in light of Foucauldian insights on government and power/knowledge and material-semiotic sensibilities of an actor-network theory perspective. ${ }^{16}$

This analytical focus on governing asylum has some important conceptual consequences. First and foremost, I turn away from an understanding of asylum as a legal status produced in a discrete decision. A narrow focus on individual cases and decision-making has been shown to often foreclose the practical purposes or problems at stake (Emerson 1983; Gilboy 1991, 573). Instead I see asylum as a set of relations established in situated material-discursive practices. ${ }^{17}$ I draw upon the notion of "case-making" (Scheffer 2001; 2010) that allows me to consider how asylum cases are made in a series of "processual events" (Scheffer 2007a). In such processual events, the relationship between the state and noncitizen subjects claiming asylum is enacted: re-corded in material-discursive associations. The re-cording of applicants'

16 I am not the only one pursuing such an approach: recent contributions to migration and mobility studies have suggested similar approaches that link Foucauldian notions of governmentality or the dispositif and insights from assemblage theory or actor-network theory, namely under the heading of "migration regimes" (e.g. Haince 2010; Hess, Kasparek, and Schwertl 2018; Tazzioli 2014). However, this study is, to the best of my knowledge, the first to exemplify the merits of such an approach in the case of asylum governance.

17 This bears resemblance to Darling's $(2014,495)$ conceptualization of asylum not as a procedure or legal status, but "a material-discursive collective that takes shape differently across different spaces". 
lives in terms of asylum requires particular geographical knowledge and technologies of inscription that tie them to - and thereby produce - certain mobile territories of asylum. For my analytical perspective, this means to grasp the sovereign act of granting or rejecting protection not as an outcome of decision-making. Rather, I argue this act consists of the re-cording of lives in terms of asylum in practices of case-making. I consider such re-cording to be achieved not by individual actors but in a strategic networked arrangement of government - a dispositif (Foucault 1980, 194-95). Such a dispositif has emerged in response to a historical problematisation of asylum (Rabinow 2003) and is stabilised by its material-discursive and strategic association with political rationalities and technologies of power of a governmentality (Foucault 2006). The dispositif's (performative) enactment in practices of case-making produces particular subjectifications and territorialisations, but also opens spaces for "insurrectional politics" (Soguk 2007). 